\title{
Survival of resistant starch during the processing of atmospheric and vacuum fried instant noodles
}

\author{
Maria Gabriela VERNAZA ${ }^{1,2 *}$, Yoon Kil CHANG ${ }^{1}$
}

\begin{abstract}
The objective was to develop instant noodles (IN) made by atmospheric and vacuum frying processes, with addition of $10 \%$ of three different sources of resistant starch: resistant starch type 2 (RS2), resistant starch type 3 (RS3) and green banana flour (GBF) aiming the increasing of the fibre content. The IN obtained by atmospheric frying lost water faster and absorbed more fat. However, for both frying treatments, the RS3 noodles absorbed the least amount of oil. The greatest loss of RS occurred during the cooking stage. RS2 and GBF noodles presented a loss of RS of around 30\% during steam cooking, while the RS3 approximately $18 \%$. The frying process decreased RS content of noodles, however, during both frying process, the samples with the highest RS content at all frying times were noodles containing RS3. When comparing products obtained after 90 and $120 \mathrm{~s}$ of atmospheric and vacuum frying, respectively, it was observed that, although the frying time in vacuum process was longer, higher RS values were obtained for the three different formulations. The vacuum frying process has advantages due to the lower fat absorption (3\% less), lighter colour and a reduced conversion of RS to digestible starch, compared to atmospheric frying.
\end{abstract}

Keywords: resistant starch; green banana flour; frying.

Practical Application: The addition of resistant starch can increase the fibre content of foods.

\section{Introduction}

The instant noodle market in Brazil is increasing and hence the Brazilian pasta industries are showing interest in this segment, since it is one of the most promising category of "pasta" production because this segment has grown around 27\% in the last five years (Associação Brasileira das Indústrias de Biscoitos, Massas Alimentícias e Pães \& Bolos Industrializados, 2015). The increase in production and consumption of instant noodles is because they represent a cheap and convenient product, and also because they are quick and easy to prepare. However, since instant noodles are a deep-fried product, they contain a high level of residual oil. The consumption of high fat content products, and also with respect to the intake of fibre is important for consumers. In an attempt to increase the consumption of fibre, several alternatives have been proposed, including the development of new products that employ new ingredients that can act by increasing the nutritional and functional value of foods.

Resistant starch (RS) is a starch fraction that does not produce glucose in the body since it resists enzymatic digestion in the small intestine, but can be fermented in the colon by bacterial microflora producing mainly gas and short chain fatty acids. Due to this characteristic, resistant starch is usually considered a dietary fibre (Champ \& Faisant, 1996).

Resistant starch has also been associated with reductions in the LDL cholesterol levels (low density lipoprotein) and in the triglyceride levels in hyperlipidaemia. In addition, resistant starch contributes to colon microflora modification, and to a reduction in the risk of colon cancer. The slow digestion of resistant starch helps to control the release of glucose from the diet, especially in diabetics. Digestion over a 5- to 7-h period reduces postprandial glycaemia and insulinaemia and has the potential for increasing the period of satiety (Fuentes-Zaragoza et al., 2010).

Deep-frying is one of the most common and popular processes used in the food industry, and consists of immersing the food in hot oil to removed water. Frying involves heat and mass transfer, and includes a series of interactions between the food and the frying medium. From the point of view of the consumers, deep-fried products have very pleasant sensory characteristic (Saguy \& Dana, 2003). Vacuum frying is an alternative way of frying that increases the quality of dehydrated foods. The products are heated under pressure, which lowers the boiling point of both the frying oil and the water present in the product. Moreover, the reduction of presence of oxygen during frying inhibits some reactions such as lipid oxidation and enzymatic browning, and may help to preserve colour and nutrients present in the fried foods (Fan et al., 2005). The objective of this study was to develop instant noodles made by atmospheric and vacuum frying processes, with the addition of $10 \%$ of three different sources of resistant starch including RS2 obtained from high amylose corn starch, RS3 obtained from gelatinizated-retrogradated high amylose corn starch and green banana flour (GBF).

${ }^{1}$ Department of Food Technology, School of Food Engineering, Universidade Estadual de Campinas - UNICAMP, Campinas, SP, Brazil

${ }^{2}$ Colegio de Ciencias e Ingeniería, El Politécnico, Ingeniería En Alimentos, Universidad San Francisco de Quito, Campus Cumbayá, Quito, Ecuador

*Corresponding author: mgvernaza@usfq.edu.ec 


\section{Material and methods}

The raw-materials used in this study were: wheat flour supplied by Bunge (São Paulo, Brazil), RS2 (Hi Maize 260 supplied by National Starch, São Paulo, Brazil), RS3 (Promitor ${ }^{\mathrm{TM}}$ Resistant Starch supplied by Tate and Lyle, São Paulo, Brazil), commercial green banana flour (green nanica - Musa acuminata Cavendish, dried and ground) (GBF) provided by Belo Vale Ltda. (São Paulo, Brazil), and palm oil supplied by Agropalma (São Paulo, Brazil). Alpha-amylase type VI-B from porcine pancreas (EC 3.2.1.1), pepsin from porcine gastric mucosa (EC 3.4.23.1) and amyloglycosidase from Aspergillus niger (EC 3.2.1.3) were obtained from Sigma Co. All other reagents and chemicals were of analytical grade.

\subsection{Characterization of the raw materials}

The raw materials were characterized for: (i) moisture, according to the Approved Method 44-15 (American Association of Cereal Chemists, 2000), (ii) fat, according to the Approved Method 30-10 (American Association of Cereal Chemists, 2000), (iii) protein, according to the Approved Method 46-13 (American Association of Cereal Chemists, 2000), (iv) ash, according to the Approved Method 08-10 (American Association of Cereal Chemists, 2000), (vi) carbohydrates by difference; (vii) resistant starch according to the enzymatic methodology proposed by Goñi, et al. (1996) and (viii) colour (luminosity) measured instrumentally using a Hunter Lab colorimeter. These analyses were carried out with four replicates.

\subsection{Making of instant noodles}

The wheat flour (1000 g) (control sample) and the mixture with each resistant starch sample (10\% of each resistant starch - experimental samples) was mixed for $15 \mathrm{~min}$ in a common mixer, then $330 \mathrm{~g}$ brine solution ( $2 \%$ salt) was added and the samples were mixed in a pin mixer (Piuno Nuova, Italy) for $10 \mathrm{~min}$. The dough was then passed through the rollers of the noodle machine (Piuno, Nouva, Italy) with a $4 \mathrm{~mm}$ gap. The noodle dough sheet was folded and put through the sheeting rollers. The folding and sheeting processes were repeated twice and the sheeted dough allowed to rest for 10 minutes. It was then put through the sheeting rollers six times with progressively smaller gaps, until reaching $1.20 \mathrm{~mm}$. Finally, the noodle dough sheet was cut using the noodle cutting rolls (Piuno Nuova, Italy) with $0.9 \mathrm{~mm}$ grooves.

The fresh noodles (control and experimental) were steamed at atmospheric pressure for $6 \mathrm{~min}$ in a steam oven (Prática, Brazil), until starch gelatinization was complete, verifying by pressing a noodle between two glasses and the core disappears. Then approximately $50 \mathrm{~g}$ and $15 \mathrm{~g}$ of the steamed noodles were weighed for the atmospheric and vacuum frying processes, respectively. Palm oil was used and for both processes and the fryers were set to the required frying temperatures and left for $1 \mathrm{~h}$ to ensure equilibrium of the oil temperature.

For the conventional frying process at atmospheric pressure, a $4 \mathrm{~L}$ fryer (Gastromac, Brazil) was used. The weighed noodles were placed in a covered stainless steel basket to prevent them from floating in the oil, and were then immersed in the hot oil at $150 \pm 3{ }^{\circ} \mathrm{C}$. At the end of each frying interval, the basket was lifted from the oil and the samples removed from the basket and placed under a fan on paper towels to remove the excess oil.

Vacuum frying was carried out in an electric vacuum cooker (Gastrovac, Barcelona, Spain) with a capacity of $7 \mathrm{~L}$, however, only enough oil to cover the stainless steel basket was added. The cooker was thermostatically controlled to maintain $110 \pm 3{ }^{\circ} \mathrm{C}$. A minimum pressure of -0.8 bars was reached, which was used for all the experiments. The weighed samples were placed in a covered stainless steel basket to prevent the samples from floating in the oil. In the vacuum fryer the basket can be placed in two positions: raised and submerged in the oil. Each frying operation consisted of an initial depressurization step with the product above the hot oil $\left(110 \pm 3^{\circ} \mathrm{C}\right)$, followed by immersion of the basket into the oil as soon as the vacuum reached the target value. At the end of each frying time, the basket was removed from the oil and left in the raised position for $30 \mathrm{~s}$, before the pressurization process. Once the vacuum was broken, the samples were removed from the basket and placed under a fan on paper towels to remove the excess oil.

The noodles were fried for $30,60,90$ or $120 \mathrm{~s}$ in the atmospheric frying process and for 30,60, 90, 120 or $150 \mathrm{~s}$ for the vacuum process.

\subsection{Characterization of the instant noodles}

The instant noodles were characterized for oil absorption according to the Approved Method 30-25 (American Association of Cereal Chemists, 2000), moisture content according to the Approved Method 44-15 (American Association of Cereal Chemists, 2000) and resistant starch content using the methodology proposed by Goñi et al. (1996). These analyses were carried out with four replicates.

The noodles obtained after $90 \mathrm{~s}$ of conventional frying and after $120 \mathrm{~s}$ of vacuum frying were characterized, in addition to the analysis mentioned above, with respect to their colour using the Hunter Lab colorimeter and texture (firmness) using the A/LKB probe of the TA-XT2i texturometer (Stable Micro Systems, England), with a maximum load of $50 \mathrm{~kg}$, equipped with the Texture Expert software for the data analysis. The test conditions were: pre-test and test speed: $0.17 \mathrm{~mm} / \mathrm{s}$; post-test speed: $10 \mathrm{~mm} / \mathrm{s}$; cut distance: $4.7 \mathrm{~mm}$; trigger type: button, trigger force $10 \mathrm{~g}$ and measured in compression force. Four and seven repetitions were performed for the colour and texture analysis, respectively.

\subsection{Statistical analysis}

The results obtained were statistically analysed by ANOVA and Tukey test and Dunnet test when comparing with the control, using the Statistic 5.0 program (Stat Soft, Inc., Tulsa, OK, USA), aiming to identify the existence of significant differences $(\mathrm{p} \leq 0.05)$ between samples and processes.

\section{Results and discussion}

\subsection{Characterization of the raw materials}

Table 1 shows the proximate composition of the raw-materials (wheat flour, RS2, RS3 and GBF on a wet weight basis. The proximate composition of the wheat flour showed that it 
had a high carbohydrate content, middle-high protein content and low ash content. The moisture content of the wheat flour was $12.61 \%$, within the limit set by Resolution RDC No. 263, September 22 $2^{\text {nd }}, 2005$, ANVISA (Brasil, 2008), which stipulated that the moisture content of flour should not exceed $15 \%$, since this influences conservation of the quality, also being one of the main factors accelerating chemical and enzymatic reactions and microbial growth.

Table 1 shows that the moisture contents of the RS2, RS3 and GBF were $11.44 \%, 10.16 \%$ and $8.91 \%$, respectively, within the limits of ANVISA (Brasil, 2008) that permit a maximum moisture content of $15 \%$ in flours and starches. The average value for fat content of GBF was $0.36 \%$ (w.w.b.), lower than those reported by other authors such as Borges et al. (2009) and Fasolin et al. (2007), who reported values of $0.68 \%$ and $1.89 \%$ (w.w.b) respectively. The crude protein content was $4.99 \%$, similar to the values found by Borges et al. (2009) and Fasolin et al. (2007), who reported protein values of $4.50 \%$ and $4.45 \%$, respectively. The average value found for the ash content in the present study was $3.16 \%$. The ash represents the minerals present in the material, such as potassium, iron, calcium, magnesium, sulphur and nitrogen (Fasolin et al., 2007; Borges et al., 2009).

The resistant starch contents (RS) of the wheat flour, RS2, RS3 and GBF were $2.13 \%, 44.05 \%, 62.34 \%$ and $45.70 \%$, respectively. The wheat flour and RS3 were statistically different from all the samples, whilst there was no significant difference between RS2 and GBF by the Tukey test $(\mathrm{p}<0.05)$. With respect to the wheat flour, other authors reported lower RS contents than those found in the present study. Tharanathan \& Tharanathan (2001) reported a resistant starch content of $0.8 \%$ in wheat flour and Goñi et al. (1996) reported values for RS between $1.63 \%$ and $1.93 \%$ for wheat flour.

The RS2 used in this study and the resistant starch found in the green banana flour (GBF) are resistant starch type 2 (RS2). RS2 are the native uncooked granules from certain starches, such as those in raw potatoes and green bananas, which are highly resistant to digestion by the enzyme $\alpha$-amylase, and in the present research RS2 contained $44.05 \%$ of resistant starch content whilst GBF presented $45.70 \%$. RS3 is a resistant starch type 3, obtained after starch gelatinization and retrogradation due to cooling and gel aging, forming a partially crystalline structure, insoluble and resistant to enzymatic digestion, but different from the initial conformation. RS3 is the most common and most important resistant starch from a technological point of view, and in the present research, RS3 presented around $60 \%$ of resistant starch. With respect to the green banana flour, the RS content depends on the variety and method of obtaining the sample. The authors Tribess et al. (2009) found RS contents in green banana flour from the "Nanicão" banana variety (Musa acuminata Cavendish subgroup) that ranged from 40.9 to $58.5 \%$ on a dry weight basis, depending on the drying conditions (drying temperature and air velocity). Ovando-Martinez et al. (2009) reported a $42.5 \%$ RS value in green banana flour from the variety Musa paradisiaca L., obtained by drying slices of peeled green banana at $50{ }^{\circ} \mathrm{C}$ using a convective heated air dryer.

Figure 1 shows the values for the luminosity $\left(L^{*}\right)$ of raw-materials. The lightest sample (higher $L^{*}$ value) was RS2, whilst GBF was the darkest. The wheat flour had an intermediate value for luminosity. As shown in Figure 1, by adding $10 \%$ of each resistant starch to the wheat flour, the mixtures with $10 \%$ RS2 and RS3 showed similar values for $\mathrm{L}^{\star}$, indicating that there was no significant change in the colour of the wheat flour. However, when $10 \%$ GBF was added, the colour of the mixture became significantly darker (lower $\mathrm{L}^{*}$ value). In the production of instant noodles without the addition of flours from other sources, an adequate wheat flour should have a low pigment content ( $L^{*}$ value $>90$ ), so a recommended flour should have a low ash content, which is usually achieved in a low extraction flour. However, when other ingredients are added to the formulation to increase the functional quality (bran, fibre and other flours) the colour of the pasta can be darker.

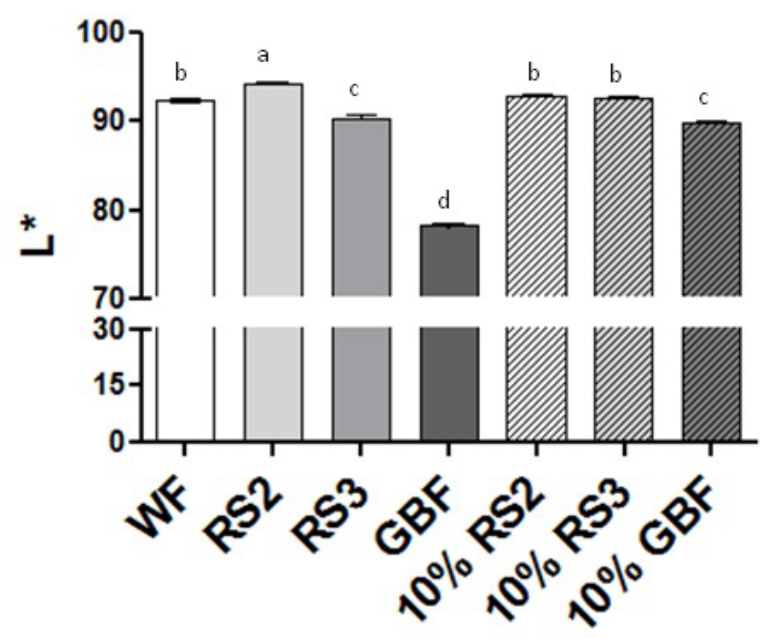

Figure 1. Luminosity $\left(\mathrm{L}^{\star}\right)$ of wheat flour (WF), RS2, RS3, GBF and the mixtures with $10 \%$ of each simple (Averages with different letters show significant differences between samples by Tukey test $(\mathrm{p}<0.05))$.

Table 1. Proximate analysis (\%) of wheat flour, RS2, RS3 and green banana flour.

\begin{tabular}{ccccc}
\hline Component & Flour & RS2 & RS3 & GBF \\
\hline Moisture $^{*}$ & $12.61 \pm 0.07^{\mathrm{a}}$ & $11.44 \pm 0.03^{\mathrm{b}}$ & $10.16 \pm 0.07^{\mathrm{c}}$ & $8.91 \pm 0.05^{\mathrm{d}}$ \\
Fat $^{*}$ & $0.77 \pm 0.005^{\mathrm{b}}$ & $0.12 \pm 0.002^{\mathrm{c}}$ & $0.08 \pm 0.002^{\mathrm{d}}$ & $0.36 \pm 0.005^{\mathrm{a}}$ \\
Protein $^{*}$ & $10.60 \pm 0.065^{\mathrm{a}}$ & $0.70 \pm 0.002^{\mathrm{c}}$ & $0.13 \pm 0.001^{\mathrm{d}}$ & $4.99 \pm 0.018^{\mathrm{b}}$ \\
Ash $^{\mathrm{a}}$ & $0.56 \pm 0.001^{\mathrm{b}}$ & $0.18 \pm 0.004^{\mathrm{c}}$ & $0.11 \pm 0.007^{\mathrm{d}}$ & $3.16 \pm 0.028^{\mathrm{a}}$ \\
Carbohydrates $^{* *}$ & 75.46 & 87.56 & 89.52 & 82.58 \\
\hline
\end{tabular}

RS2: resistant starch type 2, RS3: resistant starch type 4, GBF: green banana flour. ${ }^{\star}$ Average of four replicates. ${ }^{*}$ Calculated by difference. Averages with different letters in the same line show significant differences between samples by Tukey test $(\mathrm{p}<0.05)$. 


\subsection{Moisture loss and fat absorption of instant noodles}

Tables 2 and 3 show the moisture and fat contents determined in the noodles from both types of frying process, atmospheric and vacuum. The moisture loss in instant noodle production is very important because the evaporation of the water during the deep-frying process produces a particular structure (micro porous structure), since cooking by frying is a very fast process. The water vaporizes quickly from the surface of the noodles when immersed in the hot oil $\left(135-160^{\circ} \mathrm{C}\right)$. The dehydration of the external surface causes water to migrate from the interior to the exterior of the noodle strands, resulting in a porous spongy structure. Eventually, the water evaporated from the noodles is replaced by oil. Small pores are formed into the noodles which serve as channels for rehydration. The high oil content of the noodles allows them to be separated easily when they are cooked (Hou, 2001).

During atmospheric and vacuum frying, it was observed that the RS2 noodles absorbed more oil than the others at $90 \mathrm{~s}$. However, for both frying treatments, the RS3 noodles absorbed the least amount of oil (Table 3).

The noodles made by atmospheric frying lost more water than those made by vacuum frying, this was probably due to the difference in the temperature used. Whilst in conventional frying the oil temperature was around $150^{\circ} \mathrm{C}$, in vacuum frying the temperature reached only $110^{\circ} \mathrm{C}$. The noodles obtained by vacuum frying were obtained in $120 \mathrm{~s}$, whereas those obtained by the atmospheric process were obtained in $90 \mathrm{~s}$.

During deep-frying the oil absorbed is very important from the economic and nutritional points of view since it increases the production costs and decreases the shelf life, due to oxidative rancidity (Wu et al., 2006). In addition, the high degree of residual oil in the fried noodles is a, cause for concern with respect to health, since excessive fat intakes, especially of saturated fat, is associated with obesity problems, cardiovascular diseases and other health problems (Saguy \& Dana, 2003).

There were significant differences in the moisture and fat contents between the instant noodles produced by atmospheric and vacuum frying, when analysed for the same frying time by the Dunnet test $(\mathrm{p}<0.05)$. However, this difference was not as high as expected, since other authors have reported a reduction of up to $45 \%$ in fat absorption using vacuum technology (Garayo \& Moreira, 2002; Mariscal \& Bouchon, 2008; Dueik, et al., 2010). However, other authors obtained different results when studying the vacuum frying process, reporting an increase in oil absorption when using this technology (Tan \& Mittal, 2006; Troncoso \& Pedreschi, 2009).

There are several theories related to fat absorption in vacuum-fried products (Garayo \& Moreira, 2002; Fan et al., 2005). However, the theory that best fits the present work was that of the researchers Troncoso et al. (2009), who explained that

Table 2. Moisture contents of instant noodles obtained by atmospheric and vacuum frying at different times.

\begin{tabular}{|c|c|c|c|c|c|c|}
\hline & & \multicolumn{5}{|c|}{ Moisture (\%) } \\
\hline & & \multicolumn{5}{|c|}{ Time $(\mathrm{s})$} \\
\hline & & 30 & 60 & 90 & 120 & 150 \\
\hline & Control & $2.31 \pm 0.027^{\mathrm{F} *}$ & $1.94 \pm 0.157^{\mathrm{D} *}$ & $1.43 \pm 0.101^{\mathrm{E} *}$ & $1.42 \pm 0.027^{\mathrm{D} *}$ & \\
\hline \multirow{3}{*}{$\begin{array}{l}\text { Atmospheric } \\
\text { frying* }\end{array}$} & RS2 noodles & $2.93 \pm 0.040^{\mathrm{aB}}$ & $1.16 \pm 0.110^{\mathrm{bE}}$ & $1.09 \pm 0.027^{\mathrm{bEF} *}$ & $0.88 \pm 0.009^{\mathrm{cE}}$ & - \\
\hline & RS3 noodles & $3.44 \pm 0.036^{\mathrm{aC}}$ & $1.19 \pm 0.073^{\mathrm{bE}}$ & $0.95 \pm 0030^{\mathrm{cF}}$ & $0.99 \pm 0.020^{\mathrm{cB}}$ & - \\
\hline & GBF noodles & $2.89 \pm 0.030^{\mathrm{aA}}$ & $1.95 \pm 0.089^{\mathrm{bD} *}$ & $1.94 \pm 0.030^{\mathrm{bD}}$ & $1.75 \pm 0.053^{\mathrm{cD} *}$ & - \\
\hline \multirow{3}{*}{$\begin{array}{l}\text { Vacuum } \\
\text { frying }\end{array}$} & RS2 noodles & $13.08 \pm 0.045^{\mathrm{aE}}$ & $7.74 \pm 0.031^{\mathrm{bB}}$ & $7.35 \pm 0.034^{\mathrm{cA}}$ & $5.33 \pm 0.056^{\mathrm{dB}}$ & $4.31 \pm 0.040^{\mathrm{eC}}$ \\
\hline & RS3 noodles & $11.42 \pm 0.065^{\mathrm{aD}}$ & $8.08 \pm 0.035^{\mathrm{bC}}$ & $5.85 \pm 0.020^{c \mathrm{C}}$ & $5.57 \pm 0.033^{\mathrm{dC}}$ & $4.61 \pm 0.061^{\mathrm{eB}}$ \\
\hline & GBF noodles & $9.71 \pm 0.072^{\mathrm{aE}}$ & $6.57 \pm 0.046^{\mathrm{bA}}$ & $6.22 \pm 0.018^{\mathrm{B}}$ & $5.44 \pm 0.059^{\mathrm{dA}}$ & $4.79 \pm 0.037^{\mathrm{eA}}$ \\
\hline
\end{tabular}

All data are an average of four replicates. ${ }^{*}$ Temperature during atmospheric frying $=150 \pm 3{ }^{\circ} \mathrm{C} ;{ }^{* *}$ Temperature and pressure during vacuum frying $=110 \pm 3{ }^{\circ} \mathrm{C}$ and -0.8 bar. Averages with different small letters in the same line show significant differences between the times for the same sample by Tukey test ( $\mathrm{p}<0.05)$. Averages with different capital letters in the same column show significant differences between each process by Tukey test and with * by Dunnet test $(\mathrm{p}<0.05)$.

Table 3. Fat contents of instant noodles obtained by atmospheric and vacuum frying at different times.

\begin{tabular}{|c|c|c|c|c|c|c|}
\hline & & \multicolumn{5}{|c|}{ Fat (\%) } \\
\hline & & \multicolumn{5}{|c|}{ Time (s) } \\
\hline & & 30 & 60 & 90 & 120 & 150 \\
\hline & control & $22.38 \pm 0.083^{\mathrm{A} \star}$ & $24.11 \pm 0.085^{\mathrm{A} *}$ & $25.33 \pm 0.074^{\mathrm{B} *}$ & $26.38 \pm 0.051^{\mathrm{A} \star}$ & \\
\hline \multirow{3}{*}{$\begin{array}{c}\text { Atmospheric } \\
\text { frying* }\end{array}$} & RS2 noodles & $21.98 \pm 0.208^{\mathrm{dA} *}$ & $24.35 \pm 0.180^{c A *}$ & $26.44 \pm 0.104^{\mathrm{bA}}$ & $27.34 \pm 0.284^{\mathrm{aB}}$ & - \\
\hline & RS3 noodles & $21.58 \pm 0.639^{\mathrm{cA} \star}$ & $23.31 \pm 0.294^{\mathrm{bB}}$ & $23.56 \pm 0.274^{\mathrm{bD}}$ & $25.44 \pm 0.174^{\mathrm{aC}}$ & - \\
\hline & GBF noodles & $23.04 \pm 1.516^{\mathrm{bA} *}$ & $23.90 \pm 0.175^{\mathrm{bA} *}$ & $24.75 \pm 0.076 \mathrm{a}^{\mathrm{bC}}$ & $26.29 \pm 0.159^{\mathrm{aB}}$ & - \\
\hline \multirow{3}{*}{$\begin{array}{l}\text { Vacuum } \\
\text { Frying }\end{array}$} & RS2 noodles & $15.84 \pm 0.139^{\mathrm{dB}}$ & $16.99 \pm 0.294^{\mathrm{cD}}$ & $22.45 \pm 0.062^{\mathrm{bE}}$ & $23.61 \pm 0.187^{\mathrm{aE}}$ & $23.79 \pm 0.065^{\mathrm{aB}}$ \\
\hline & RS3 noodles & $13.12 \pm 0.134^{\mathrm{eC}}$ & $15.41 \pm 0.133^{\mathrm{dE}}$ & $20.61 \pm 0.386^{\mathrm{cF}}$ & $21.70 \pm 0.228^{\mathrm{bF}}$ & $22.66 \pm 0.104^{\mathrm{aC}}$ \\
\hline & GBF noodles & $17.47 \pm 0.101^{\mathrm{eB}}$ & $18.27 \pm 0.009^{\mathrm{dC}}$ & $21.97 \pm 0.117^{\mathrm{cE}}$ & $24.52 \pm 0.178^{\mathrm{bD}}$ & $25.10 \pm 0.106^{\mathrm{aA}}$ \\
\hline
\end{tabular}

All data are an average of four replicates. ${ }^{*}$ Temperature during atmospheric frying $=150 \pm 3{ }^{\circ} \mathrm{C} ;{ }^{* *}$ Temperature and pressure during vacuum frying $=110 \pm 3{ }^{\circ} \mathrm{C}$ and -0.8 bar. Averages with different small letters in the same line show significant differences between the times for the same sample by Tukey test ( $p<0.05)$. Averages with different capital letters in the same column show significant differences between the processes by Tukey test and with * by Dunnet test $(\mathrm{p}<0.05)$. 
it was not possible to reduce the fat absorption of vacuum-fried products without using a de-oiling mechanism. In the present work, the excess fat was removed using paper towels after the frying processes.

\subsection{Resistant starch degradation in the production of instant noodles}

Table 4 show the values for the resistant starch content at each time during the atmospheric and vacuum frying processes, respectively, and also show the resistant starch content of the instant noodles before and after the steam cooking process. It was observed that the greatest loss in resistant starch occurred during the steam cooking stage. Unlike these results, Dhital et al. (2010) reported that the steam cooking increased the resistant starch content of noodles due to the gelatinization and retrogradation of the starch. However, these authors determined the resistant starch content during the processing of wheat noodles and not due to the addition of different sources of resistant starch that can be heat sensitive. The RS2 and GBF noodles presented a loss of resistant starch of around 30\% during steam cooking, while the RS3 noodles presented a loss of approximately $18 \%$. However, the control sample did not present a loss of resistant starch, although there was an increase in the value, it was not significantly different $(\mathrm{P}<0.05)$.

The frying process decreased the resistant starch content of noodles. Due to the moisture content of the noodles (around 50\%), the thermal degradation of amylose molecules is prevented. As the temperature of frying is very high $\left(\sim 150{ }^{\circ} \mathrm{C}\right)$, there is less possibility of alignment and of the leach of amylose fractions responsible for the double helices and the crystalline structure that is resistant to the enzyme digestion. Since frying is accompanied by a quick moisture loss, there is less in the fried samples to cause the retrogradation of the starch (Dhital et al., 2010). During both frying process, atmospheric and vacuum, the samples with the highest resistant starch content at all frying times were noodles containing RS3 starch.

During the frying process, the resistant starch content decreased with processing time. When comparing the products obtained after 90 and 120 s of atmospheric and vacuum frying, respectively, it could be observed that, although the frying time in the vacuum process was longer, higher resistant starch values were obtained for the three different formulations (Table 4). Therefore, it can be concluded that the use of vacuum frying to prepare noodles helps to prevent the conversion of resistant starch to rapidly digestible in fried products. Several researchers have used the vacuum frying process both to reduce the oil content and to slow the degradation of functional compounds such as antioxidants, and even to prevent the formation of undesirable compounds (Dueik et al., 2010; Silva \& Moreira, 2008).

Analysing the values shown in Table 4, it can be concluded that the type of resistant starch that best supported the technological processes, such as steam cooking and frying, in the production of instant noodles, was resistant starch type 3 (RS3). This was due to its structure, which is more compact and stable because of the processes used to obtain it, such as gelatinization and retrogradation.

\subsection{Colour of instant noodles}

Figure 2 a shows the values for luminosity $\left(\mathrm{L}^{*}\right)$ of the three formulations of noodles. In general, the colour parameters represent an important product appearance feature (Delcour \& Hoseney, 2010). The $\mathrm{L}^{*}$ value is a critical parameter in the frying industry and is usually the first quality attribute evaluated by the consumers when the product acceptance is determined. Low values for $\mathrm{L}^{*}$ indicate a darker colour and are usually associated with non-enzymatic browning reactions (Dueik et al., 2010). Figure 2 a shows that for both frying processes, there were no significant differences between the RS2 10 and RS3 noodles, although the GBF noodles presented lower values for luminosity and hence a darker colour. The darkening of the GBF noodles can be attributed to the dark colour of the green banana flour used as one of the raw materials. In agreement with this result, Choo \& Aziz (2010) and Vernaza et al. (2011) also reported a darkening in colour when using green banana in the production of noodles.

There was a significant difference between the noodles obtained with the two frying processes. The noodles obtained by vacuum frying showed greater values for luminosity (lighter colour) when compared to those obtained by atmospheric frying. The darker colour obtained with atmospheric frying was due to the higher intensity of the heat treatment, since elevated temperatures can cause changes in colour due to the faster

Table 4. Resistant starch of instant noodles obtained by atmospheric and vacuum frying at different times.

\begin{tabular}{|c|c|c|c|c|c|c|c|c|}
\hline & \multirow{2}{*}{ Noodle type } & \multirow{2}{*}{ Raw noodles } & \multirow{2}{*}{$\begin{array}{c}\text { Steam cooked } \\
\text { noodles }\end{array}$} & \multicolumn{5}{|c|}{ Frying time } \\
\hline & & & & $30 \mathrm{~s}$ & $60 \mathrm{~s}$ & $90 \mathrm{~s}$ & $120 \mathrm{~s}$ & $150 \mathrm{~s}$ \\
\hline & control & $2.12 \pm 0.14^{\mathrm{a} \star}$ & $2.39 \pm 0.19^{a \star}$ & $1.13 \pm 0.33^{\mathrm{bC} *}$ & $1.01 \pm 0.12^{\mathrm{bcE} *}$ & $0.83 \pm 0.10^{\text {cE* }}$ & $0.79 \pm 0.15^{\mathrm{cD} *}$ & - \\
\hline \multirow{3}{*}{$\begin{array}{l}\text { Atmospheric } \\
\text { frying }\end{array}$} & RS2 noodles & $8.93 \pm 0.20^{\mathrm{a}}$ & $6.31 \pm 0.48^{\mathrm{b}}$ & $6.14 \pm 0.44^{\mathrm{cA}}$ & $6.06 \pm 0.16^{\mathrm{cB}}$ & $5.60 \pm 0.10^{\mathrm{cdB}}$ & $4.91 \pm 0.37^{\mathrm{d} A \mathrm{~B}}$ & - \\
\hline & RS3 noodles & $9.84 \pm 0.23^{\mathrm{a}}$ & $8.05 \pm 0.12^{\mathrm{b}}$ & $6.57 \pm 0.66 b^{c A}$ & $6.24 \pm 0.29^{\mathrm{cAB}}$ & $5.74 \pm 0.09^{\mathrm{cdB}}$ & $5.28 \pm 0.24^{\mathrm{deBC}}$ & - \\
\hline & GBF noodles & $7.28 \pm 0.29^{\mathrm{a}}$ & $5.28 \pm 0.60^{\mathrm{b}}$ & $4.45 \pm 0.75 b^{c B}$ & $4.37 \pm 0.69^{\mathrm{cD}}$ & $3.98 \pm 0.55^{\mathrm{cD}}$ & $3.90 \pm 0.24^{\mathrm{cC}}$ & - \\
\hline $\begin{array}{l}\text { Vacuum } \\
\text { Frying }^{\star *}\end{array}$ & RS2 noodles & $8.93 \pm 0.20^{\mathrm{a}}$ & $6.31 \pm 0.48^{\mathrm{b}}$ & $6.53 \pm 0.34^{\mathrm{bcA}}$ & $6.29 \pm 0.50^{\mathrm{bcB}}$ & $5.90 \pm 0.25^{\mathrm{bcB}}$ & $5.87 \pm 0.70^{\text {bcAB }}$ & $5.36 \pm 0.21^{\mathrm{dB}}$ \\
\hline
\end{tabular}

All data are an average of four replicates. ${ }^{*}$ Temperature during atmospheric frying $=150 \pm 3{ }^{\circ} \mathrm{C} ;{ }^{* *}$ Temperature and pressure during vacuum frying $=110 \pm 3{ }^{\circ} \mathrm{C}$ and -0.8 bar. Averages with different small letters in the same line show significant differences between the times for the same sample by Tukey test ( $\mathrm{p}<0.05)$. Averages with different capital letters in the same column show significant differences between the processes by Tukey test and with * by Dunnet test $(\mathrm{p}<0.05)$. 


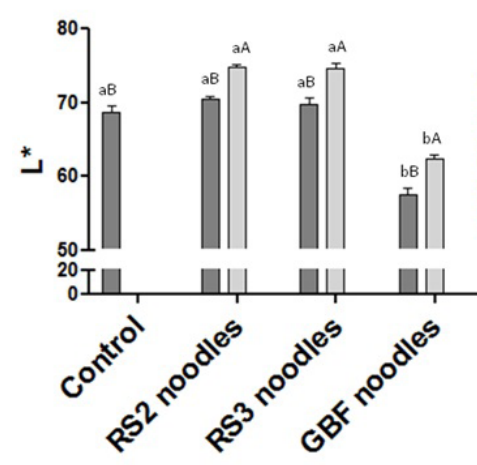

a)

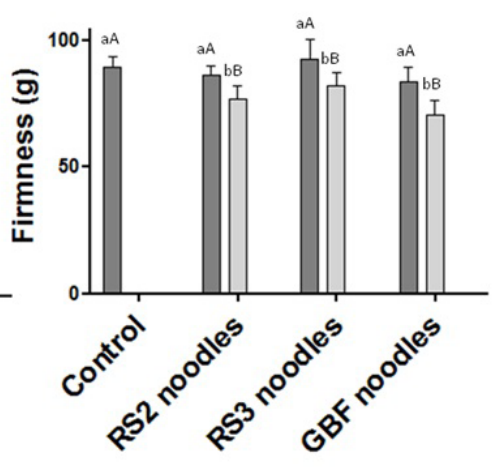

b)

Figure 2. (a) Luminosity $\left(\mathrm{L}^{\star}\right)$ and (b) Firmness of instant noodles (Averages with different small letters show significant differences between samples and with capital letters show significant differences between processes by Dunnet test $(\mathrm{p}<0.05))$.

development of the Maillard reaction and due to the production of degradation compounds in the oil.

These results agree with those of other researchers, who reported higher values for $\mathrm{L}^{*}$ for products fried under vacuum conditions than for products obtained using an atmospheric frying process (Garayo \& Moreira 2002; Silva \& Moreira, 2008; Mariscal \& Bouchon, 2008; Dueik et al., 2010).

\subsection{Texture of instant noodles}

Figure $2 \mathrm{~b}$ shows the values for firmness of the different instant noodles obtained by the two frying processes. The frying process removes most of the moisture from the product and modifies the internal structure, determining the physical and sensory properties of the final product. With respect to firmness, for both types of frying process a reduction in firmness was observed when $10 \%$ of GBF was added (Figure $2 \mathrm{~b}$ ), which can be explained by the decrease in the viscoelastic properties when $10 \%$ of GBF was added to the wheat flour. The addition of GBF dilutes the wheat proteins (gluten) making the structure weaker and losing their viscoelastic properties (Vernaza et al., 2011). On the other hand, the addition of $10 \%$ RS2 or RS3 to the wheat flour did not result in a significant change in the rheological properties (Vernaza \& Chang, 2010) and the formulation RS3 showed the firmest noodles (Figure 2b).

\section{Conclusion}

The instant noodles made with RS3 presented the best technological properties in the production of instant noodles, showing the lowest values for fat absorption, and the highest values for firmness and resistant starch content.

The vacuum frying process showed advantages in the production of instant noodles, due to the lower oil absorption, lighter colour of the noodles and reduced degradation of resistant starch. However, in future studies, it is important to considerer the use of a de-oiling mechanism after the vacuum frying, to reduce even more the fat content in fried products.

\section{Acknowledgements}

The authors are grateful to FAPESP (Process number 08/02474-1) for the financial assistance. They are also grateful to Bunge, Agropalma, National Starch and Tate and Lyle for the donations of wheat flour, palm oil, RS2 and RS3, respect.

\section{References}

American Association of Cereal Chemists - AACC. (2000). American Association of Cereal Chemists: Approved Methods (10th ed.). St. Paul: AACC.

Associação Brasileira das Indústrias de Biscoitos, Massas Alimentícias e Pães \& Bolos Industrializados - ABIMAPI. (2015). São Paulo: ABIMAPI. Retrieved from http://www.abimapi.com.br/index.php

Borges, A. M., Pereira, J., \& Lucena, E. M. P. (2009). Caracterização da farinha de banana verde. Ciência e Tecnologia de Alimentos, 29(2), 333-339. http://dx.doi.org/10.1590/S0101-20612009000200015.

Brasil. Ministério da Saúde. Agência Nacional de Vigilância Sanitária. (2008, September 22). Resolução RDC No 263 de 22 de setembro de 2005. Aprova o Regulamento Técnico para Produtos de Cereais, Amidos, Farinhas e Farelos. Diário Oficial [da] República Federativa do Brasil. Retrieved from htpp://www.e-legis.bvs.br

Champ, M., \& Faisant, N. (1996). Resistant starch: analytical and physiological aspects. Boletim SBCTA, 30, 37-43.

Choo, C. L., \& Aziz, N. A. A. (2010). Effects of banana flour and $\beta$-glucan on the nutritional and sensory evaluation of noodles. Food Chemistry, 119(1), 34-40. http://dx.doi.org/10.1016/j.foodchem.2009.05.004.

Delcour, J. A., \& Hoseney, C. R. (2010). Principles of cereal science and technology (3rd ed.). St. Paul: AACC International.

Dhital, S., Katawal, S. B., \& Shrestha, A. K. (2010). Formation of resistant starch during processing and storage of instant noodles. International Journal of Food Properties, 13(3), 454-463. http:// dx.doi.org/10.1080/10942910802627091.

Dueik, V., Robert, P., \& Bouchon, P. (2010). Vacuum frying reduces oil uptake and improves the quality parameters of carrot crisps. Food Chemistry, 119(3), 1143-1149. http://dx.doi.org/10.1016/j. foodchem.2009.08.027.

Fan, L. P., Zhang, M., Xiao, G. N., Sun, J., \& Tao, Q. (2005). The optimization of vacuum frying to dehydrate carrot chips. International 
Journal of Food Science \& Technology, 40(9), 911-919. http://dx.doi. org/10.1111/j.1365-2621.2005.00985.x.

Fasolin, L. H., Almeida, G. C., Castanho, P. S., \& Netto-Oliveira, E. R. (2007). Biscoitos produzidos com farinha de banana: avaliações química, física e sensorial. Ciência e Tecnologia de Alimentos, 27(3), 524-529. http://dx.doi.org/10.1590/S0101-20612007000300016.

Fuentes-Zaragoza, E., Riquelme-Navarrete, M. J., Sánchez-Zapata, E., \& Pérez-Álvarez, J. A. (2010). Resistant starch as functional ingredient: a review. Food Research International, 43(4), 931-942. http://dx.doi. org/10.1016/j.foodres.2010.02.004.

Garayo, J., \& Moreira, R. (2002). Vacuum frying of potato chips. Journal of Food Engineering, 55(2), 181-191. http://dx.doi.org/10.1016/ S0260-8774(02)00062-6.

Goñi, I., García-Diz, L., Mañas, E., \& Saura-Calixto, F. (1996). Analysis of resistant starch: a method for foods and food products. Food Chemistry, 56(4), 445-449. http://dx.doi.org/10.1016/0308-8146(95)00222-7.

Hou, G. Q. (2001). Oriental noodles. Advances in Food and Nutrition Research, 43, 143-193. PMid:11285682. http://dx.doi.org/10.1016/ S1043-4526(01)43004-X

Mariscal, M., \& Bouchon, P. (2008). Comparison between atmospheric and vacuum frying of apple slices. Food Chemistry, 107(4), 15611569. http://dx.doi.org/10.1016/j.foodchem.2007.09.031.

Ovando-Martinez, M., Sáyago-Ayerdib, S., Agama-Acevedo, E., Goñi, I., \& Bello-Pérez, L. A. (2009). Unripe banana flour as an ingredient to increase the undigestible carbohydrates of pasta. Food Chemistry, 113(1), 121-126. http://dx.doi.org/10.1016/j.foodchem.2008.07.035.

Saguy, I. S., \& Dana, D. (2003). Integrated approach to deep fat frying: engineering, nutrition, health and consumer aspects. Journal of Food Engineering, 56(2-3), 143-152. http://dx.doi.org/10.1016/ S0260-8774(02)00243-1.

Silva, P., \& Moreira, R. (2008). Vacuum frying of high-quality fruit and vegetable-based snacks. Food Science and Technology (Campinas.), 41, 1758-1767.
Tan, K. J., \& Mittal, G. S. (2006). Physicochemical properties changes of donuts during vacuum frying. International Journal of Food Properties, 9(1), 85-98. http://dx.doi.org/10.1080/10942910500473947.

Tharanathan, M., \& Tharanathan, R. N. (2001). Resistant starch in wheat-based products: isolation and characterization. Journal of Cereal Science, 34(1), 73-84. http://dx.doi.org/10.1006/jcrs.2000.0383.

Tribess, T. B., Hernández-Uribe, J. P., Médez-Montealvo, M. G. C., Menezes, E. W., Bello-Perez, L. A., \& Tadini, C. C. (2009). Thermal properties and resistant starch content of green banana flour (Musa cavendishii) produced at different drying conditions. LWT - Food Science and Technology (Campinas.), 42, 1022-1025.

Troncoso, E., Pedreschi, F., \& Zuniga, R. N. (2009). Comparative study of physical and sensory properties of pre-treated potato slices during vacuum and atmospheric frying. LWT - Food Science and Technology (Campinas.), 42, 187-195.

Troncoso, E., \& Pedreschi, F. (2009). Modeling water loss and oil uptake during vacuum frying of pre-treated potato slices. LWT - Food Science and Technology (Campinas.), 42, 1164-1173.

Vernaza, M. G., \& Chang, Y. K. (2010). Development of functional instant noodles (Ph.D. thesis). Faculty of Food Engineering, Universidade Estadual de Campinas, Campinas.

Vernaza, M. G., Gularte, M. A., \& Chang, Y. K. (2011). Addition of green banana flour to instant noodles: rheological and technological properties. Ciência e Agrotecnologia, 35(6), 1157-1165. http://dx.doi. org/10.1590/S1413-70542011000600016.

Wu, J., Aluko, R. E., \& Corke, H. (2006). Partial least-squares regression study of the effect of wheat flour composition, protein and starch quality characteristics on oil content of steamed-and-fried instant noodles. Journal of Cereal Science, 44(2), 117-126. http://dx.doi. org/10.1016/j.jcs.2006.05.008. 